\title{
Minichromosome maintenance proteins 2 and 5 in non-benign epithelial ovarian tumours: relationship with cell cycle regulators and prognostic implications
}

\author{
H Gakiopoulou',4, P Korkolopoulou*, I,4, G Levidou', I Thymara', A Saetta', C Piperi', N Givalos', \\ I Vassilopoulos', K Ventouri', A Tsenga', A Bamias', M-A Dimopoulos ${ }^{3}$, E Agapitos' and E Patsouris' \\ 'First Department of Pathology, Athens University, School of Medicine, GR-I 1527 Athens, Greece; '2Department of Biological Chemistry, Athens \\ University, School of Medicine, GR-I 1527 Athens, Greece; ${ }^{3}$ Department of Therapeutics, Alexandra General Hospital, Athens University School of \\ Medicine, GR $1 / 528$ Athens, Greece
}

\begin{abstract}
Minichromosome maintenance proteins (MCM) have recently emerged as novel proliferation markers with prognostic implications in several tumour types. This is the first study investigating MCM-2 and MCM-5 immunohistochemical expression in a series of ovarian adenocarcinomas and low malignant potential (LMP) tumours aiming to determine possible associations with clinicopathological parameters, the conventional proliferation index Ki-67, cell cycle regulators ( $553, p 27^{\text {Kipl }}, p 21^{\text {WAFI }}$ and pRb) and patients' outcome. Immunohistochemistry was applied in a series of 43 cases of ovarian LMP tumours and 85 cases of adenocarcinomas. Survival analysis was restricted to adenocarcinomas. The median MCM-2 and MCM-5 labelling indices (Lls) were significantly higher in adenocarcinomas compared to LMP tumours $(P<0.000$ I for both associations). In adenocarcinomas, the levels of $M C M-2$ and MCM-5 increased significantly with advancing tumour stage $(P=0.0052$ and $P=0.0180$, respectively), whereas both $M C M-2$ and MCM-5 increased significantly with increasing tumour grade $(P=0.0002$ and $P=0.0006$, respectively) and the presence of bulky residual disease $(P<0.000 \mathrm{I}$ in both relationships). A strong positive correlation was established between $M C M-2$ or $M C M-5$ expression level and Ki-67 LI $(P<0.000 \mathrm{I})$ as well as $p 53$ protein $(P=0.0038$ and $P=0.0500$, respectively). Moreover, $M C M-2 \mathrm{LI}$ was inversely correlated with $p 27^{\text {Kip-1 }} \mathrm{LI}(P=0.0068)$. Finally, both MCM-2 and MCM-5 were associated significantly with adverse patients' outcome in both univariate ( $\geqslant 20$ vs $>20 \%, P=0.001$ I and $\geqslant 25$ vs $<25 \%, P=0.0100$, respectively) and multivariate $(P=0.000 \mathrm{I}$ and 0.0090 , respectively) analysis. An adequately powered independent group of 45 patients was used in order to validate our results in univariate survival analysis. In this group, MCM-2 and MCM-5 expression retained their prognostic significance $(P<0.000$ I in both relationships). In conclusion, MCM-2 and MCM-5 proteins appear to be promising as prognostic markers in patients with ovarian adenocarcinomas.
\end{abstract}

British Journal of Cancer (2007) 97, I I24- | |34. doi:I0.1038/sj.bjc.6603992 www.bjcancer.com

Published online 16 October 2007

(c) 2007 Cancer Research UK

Keywords: MCM-2; MCM-5; Ki-67; ovarian low malignant potential tumours; ovarian adenocarcinomas; survival

The most consistently reported significant prognostic indicators for human ovarian cancer are disease stage, tumour grade, histologic type and extent of surgical cytoreduction (Ozols, 2002). However, there remains a significant degree of biologic heterogeneity even within the same prognostic subgroups, hampering the accurate prediction of clinical behaviour in individual cases (Ozols, 2002). Thus, gaining insight into the molecular determinants of the biologic behaviour of ovarian cancer is imperative to identify groups of patients with a particularly poor prognosis.

The rapidly advancing understanding of mammalian DNA replication has given rise to a new generation of proliferation

\footnotetext{
* Correspondence: Dr P Korkolopoulou; Vassileos Pavlou 73, Athens I5452, Greece; E-mail: pkorkol@cc.uoa.gr

${ }^{4}$ These authors contributed equally to this work.

Received 10 May 2007; revised 23 August 2007; accepted 23 August 2007; published online 16 October 2007
}

markers. Recently, positive and negative regulators of DNA replication have emerged as novel tumour biomarkers that may potentially be used for screening, estimation of prognosis and assessment of treatment response for a range of tumour types (Tachibana et al, 2005). Minichromosome maintenance (MCM) proteins drive the formation of prereplicative complexes (PRCs), which is the first key event during $G_{1}$ phase (Tye, 1999). In all eukaryotic cells, initiation of DNA synthesis is a complex multistep process tightly coupled to progression through the cell cycle (Ritzi and Knippers, 2000). In the first step, during the $G_{1}$ phase key replication initiation factors, including the origin recognition complex, the Cdc6 protein and the MCM proteins 2-7 are recruited into PRCs at future replication origins, establishing the competence of particular chromatin regions for initiation of DNA synthesis (Tye, 1999; Labib and Diffley, 2001; Lei and Tye, 2001; $\mathrm{Yu}$ et al, 2004b). The MCMs are highly conserved proteins presumed to act as an enzymatically active helicase (Labib and Diffley, 2001). In the second step, unwinding of replication origins 
and establishment of bi-directional replication forks take place to control entry into the S phase (Labib and Diffley, 2001). As the DNA is replicated, MCM proteins gradually dissociate from chromatin, ensuring that each region of DNA is replicated only once during a single cell cycle, because replicated DNA lacks functional PRCs (Labib and Diffley, 2001). As the cells leave the cell cycle to enter into the quiescent, differentiated and senescent states, the Cdc6 and MCM components of the replication initiation pathway are downregulated (Stoeber et al, 2001).

Recently, several groups have reported that MCM immunoreactivity is a specific and accurate marker for proliferating cells (Todorov et al, 1998; Freeman et al, 1999; Heidebrecht et al, 2001; Kodani et al, 2001; Stoeber et al, 2001). Other advantages of MCMs are that they do not detect cells undergoing DNA repair and they are not downregulated in proliferating cells by nutritional deprivation, which may be operating regionally in solid tumours (Osaki et al, 2002). Also, their function has been well characterised in several in vitro systems (Tye, 1999) representing a point of convergence for numerous signalling pathways involved in cell growth (Stoeber et al, 2001) and their levels change little during the cell cycle, decreasing markedly in cells with a lower proliferation rate (Todorov et al, 1994).

To the best of our knowledge, there is only one previous study assessing MCMs in ovarian neoplasia (Scott et al, 2004). However, this study has focused solely on serous neoplasms and has investigated only MCM-2 protein expression. More importantly, nothing is known about the prognostic utility of MCM proteins in ovarian cancer. The aim of the present study was to investigate the immunohistochemical expression of MCM-2 and MCM-5 proteins in a series of low malignant potential (LMP) tumours and ovarian carcinomas of all histologic types and to determine for the first time the possible associations with clinicopathologic parameters, the conventional proliferation index Ki-67, other cell cycle regulators (p53, p27 ${ }^{\mathrm{Kip} 1}, \mathrm{p} 21^{\mathrm{WAF} 1}$ and $\left.\mathrm{pRb}\right)$ and patients' outcome.

\section{MATERIALS AND METHODS}

\section{Study populations}

Patient population This is a retrospective study of 128 consecutive cases of epithelial ovarian tumours of LMP and adenocarcinomas, diagnosed and treated at Alexandra General Hospital and Iasso Gynaecologic Institute of Athens between 1989 and 1999, for whom paraffin-embedded tissue and clinical information were available. Eighty-five specimens were defined as ovarian adenocarcinomas, whereas 43 specimens fulfilled the criteria of LMP tumours (Scully and Sobin, 1987; Russel, 1994). Histologic classification of tumours was carried out according to the World Health Organization System (Scully and Sobin, 1987). Poorly differentiated adenocarcinoma was the diagnosis for those carcinomas that did not show evident cellular differentiation. Adenocarcinomas were graded as well, moderately and poorly differentiated (Scully and Sobin, 1987) and patients were assigned a clinical stage according to the International Federation of Gynecology and Obstetrics (Cancer Committee of FIGO, 1986) standards. Surgical and pathologic findings and postoperative abdomino-pelvic computerised tomography (CT) scans were used to determine the FIGO stage for the ovarian adenocarcinomas and the residual disease after the initial surgery. Persistence of tumour masses of $<2 \mathrm{~cm}$ was defined as minimal residual disease, whereas the presence of masses of $>2 \mathrm{~cm}$ in diameter was defined as bulk residual disease (Anttila et al, 1999; Sengupta et al, 2000).

All patients with carcinomas had undergone total abdominal hysterectomy with bilateral salpingo-oophorectomy followed by chemotherapy. None had received preoperative chemotherapy or radiotherapy. The clinicopathologic characteristics of these patients are summarised in Table 1. Follow-up information was
Table I Clinical data of patients in the study population with ovarian LMP tumours and adenocarcinomas

\begin{tabular}{|c|c|}
\hline Age (years) & $51.6(20-86)$ \\
\hline \multicolumn{2}{|l|}{ Histological type } \\
\hline \multicolumn{2}{|l|}{ LMP tumours } \\
\hline Serous & $29(67.4 \%)$ \\
\hline Mucinous & $14(32.6 \%)$ \\
\hline \multicolumn{2}{|l|}{ Adenocarcinomas } \\
\hline Serous & $34(40 \%)$ \\
\hline Mucinous & $10(11.76 \%)$ \\
\hline Endometrioid & $16(18.82 \%)$ \\
\hline Clear cell & $18(21.17 \%)$ \\
\hline Poorly differentiated & $3(3.5 \%)$ \\
\hline Not specified & $4(4.7 \%)$ \\
\hline \multicolumn{2}{|l|}{ Histologic grade } \\
\hline I & $13(15.3 \%)$ \\
\hline 2 & $240(47.1 \%)$ \\
\hline 3 & $32(37.6 \%)$ \\
\hline \multicolumn{2}{|l|}{ FIGO stage } \\
\hline 1 & $25(29.5 \%)$ \\
\hline$\|$ & $3(3.5 \%)$ \\
\hline III & $42(49.4 \%)$ \\
\hline IV & II (12.9\%) \\
\hline Not specified & $4(4.7 \%)$ \\
\hline \multicolumn{2}{|l|}{ Primary residual tumour } \\
\hline No & $39(45.9 \%)$ \\
\hline Yes & $46(54.1 \%)$ \\
\hline \multicolumn{2}{|l|}{ Adjuvant chemotherapy } \\
\hline Platinum-containing & $64(75.3 \%)$ \\
\hline Non platinum-containing & $21(24.7 \%)$ \\
\hline \multicolumn{2}{|l|}{ Clinical outcome } \\
\hline Died of ovarian cancer & $26(30.6 \%)$ \\
\hline Alive & $53(62.4 \%)$ \\
\hline Not specified & $6(0.7 \%)$ \\
\hline
\end{tabular}

available in 79 patients. By the time this study was undertaken, 26 patients had died of their disease after a median survival of 15.6 (range 1-60) months. The median follow-up for the remaining 53 patients was 43 (range 11.7-126) months.

\section{Validation group}

An independent set of patients with ovarian adenocarcinoma was used to validate our results of univariate survival analysis and test the validity of the chosen cutoff values for the expression of MCM-2 and MCM-5 proteins. The results of univariate survival analysis for MCM-2 and MCM-5 expression in the population group were used to calculate the required number of patients in the validation group for an adequately powered analysis (90\%) (Lachin and Foulkes, 1986). Lachin (1981) have showed that the equation relating total sample size and power for a univariate survival analysis test in simple sets is given by the following equation:

$$
\begin{aligned}
\sqrt{\mathrm{N}}\left|\lambda_{e}-\lambda_{c}\right|= & \left.Z_{\alpha} \sqrt{\phi(\bar{\lambda})\left(Q_{e}^{-1}+\right.} Q_{c}^{-1}\right)+Z_{b} \\
& \left.\sqrt{\phi\left(\lambda_{e}\right) Q_{e}^{-1}+\phi}\left(\lambda_{c}\right) Q_{c}^{-1}\right)
\end{aligned}
$$

where $\lambda_{e}, \lambda_{c}$ the respective hazard ratios in the two groups, $Q_{i}=n_{i} / N, \lambda=Q_{c} \lambda_{c}+Q_{e} \lambda_{e}$ and $\mathrm{Za}, \mathrm{Zb}$ the standard normal derivatives at levels $a$ and $b$, respectively.

Given that our study implies non-uniform patients' entry and consequently follow-up, this type can be transformed when we 
suppose the following exponential entry distribution (Lachin and Foulkes, 1986).

$$
\phi(\lambda)=\lambda^{2}\left[1+\frac{\gamma e^{-\lambda \mathrm{T}}\left[1-e^{(\lambda-\gamma) R}\right]}{\left(1-e^{-\gamma R}\right)(\lambda-\gamma)}\right]
$$

Sample size and power can be calculated by substituting this type into the above.

The validation group consisted of 45 patients with primary ovarian adenocarcinoma, diagnosed and treated at Alexandra General Hospital between 1994 and 2004, for whom paraffinembedded tissue was available. Follow-up period ranged from 1.3 to 124 months (median: 23.96 months). During this period, 16 disease-specific deaths were recorded, whereas the median (range) follow-up for the remaining 29 cases was 28.5 (9-124) months. The clinicopathologic data of the validation group are summarised in Table 2.

\section{Processing of specimens and immunohistochemistry}

Tissues were fixed immediately after removal in $10 \%$ buffered formalin and processed to paraffin wax. Four micrometres serial sections were cut from each specimen on Superfrost plus glass slides and left to dry overnight at $37^{\circ} \mathrm{C}$. In addition, from our previous investigations (Korkolopoulou et al, 2002; Konstantinidou et al, 2003; Vassilopoulos et al, 2003), results regarding the expression of p53, p $27^{\mathrm{Kip} 1}, \mathrm{pRb}, \mathrm{p} 21^{\mathrm{WAF} 1}$ and Ki-67 were available in all cases. The following monoclonal antibodies were used: (1) MCA 1859 for MCM-2 (clone CRCT2.1/D1.9H5) (Serotec Ltd, Oxford, UK, diluted 1:500 overnight) and (2) MCA 1860 for MCM-5 (clone CRCT5.1/A2.7A3) (Serotec Ltd, Oxford, UK, diluted $1: 200$ overnight). For both antibodies, antigen retrieval with

Table 2 Clinical data of patients in the validation group with ovarian adenocarcinomas

\begin{tabular}{lc}
\hline Age (years) & \\
Median (range) & $58(22-86)$ \\
Histological type & \\
Serous & $35(77.8 \%)$ \\
Mucinous & $1(2.2 \%)$ \\
Endometrioid & $3(6.7 \%)$ \\
Clear cell & $3(6.7 \%)$ \\
Poorly differentiated & $1(2.2 \%)$ \\
Not specified & $2(4.4 \%)$ \\
& \\
Histologic grade & \\
I & $4(9.3)$ \\
2 & $20(46.5)$ \\
3 & $19(44.2 \%)$ \\
FIGO stage & \\
I & $1(2.2 \%)$ \\
II & $6(13.3 \%)$ \\
III & $29(64.4 \%)$ \\
IV & $9(20.0 \%)$ \\
Primary residual tumour & \\
No & $16(35.6 \%)$ \\
Yes & $28(62.2 \%)$ \\
Not specified & $1(2.2 \%)$ \\
Adjuvant chemotherapy & \\
Platinum-containing & \\
Non platinum-containing & $34(75.6 \%)$ \\
Clinical outcome & $11(24.4 \%)$ \\
Died of ovarian cancer & \\
Alive & $29(64.4 \%)$ \\
\hline
\end{tabular}

microwaving for $30 \mathrm{~min}$, at $750 \mathrm{~W}$, in citrate buffer $\mathrm{pH} 6.0$ was required. The peroxidase-polymer-based method was used with DAKO Envision kit (DAKO, Carpinteria, CA, USA). Known positive controls (i.e. a normal tonsil) as well as negative controls (sections in which anti-MCM-2 and anti-MCM-5 antibodies were substituted by non-immune mouse serum) were also stained in each run.

Staining for MCM-2 and MCM-5 was assessed blindly (i.e. without any knowledge of the clinical data) by two observers. A difference of greater than $5 \%$ between the two assessments was observed in $7.8 \%(10 / 128)$ and $10.15 \%$ (13/128) of cases, respectively. In these cases, slides were reviewed jointly and a consensus was reached. Nuclei from about 1000 tumour cells from systematically randomised fields $(\times 40)$ throughout the entire section were counted and the labelling index (LI) was calculated as the percentage of labelled nuclei out of the total number of tumour cells counted. Whenever heterogeneous staining was encountered, counting was performed in areas of highest density of labelled cells, identified at medium magnification $(\times 20)$, because it has been proposed that these tumour areas are most likely to be of biologic significance (Wharton et al, 2001; Rodins et al, 2002). All clearly identifiable nuclear staining beyond background was recorded as positive for MCM-2 and MCM-5. No endothelial or lymphoid cells were included in the counts even though they expressed MCM-2 and MCM-5.

\section{Cell culture}

MDAH-2774 cells were serially passaged as monolayer cultures in RPMI medium, supplemented with $10 \%$ FCS, $1 \%$ L-glutamine, $50 \mathrm{mg} \mathrm{ml}^{-1}$ streptomycin and $50 \mathrm{U} \mathrm{ml}^{-1}$ penicillin (Gibco-BRL/Life Technologies, Eggenstein, Germany). The cell-culture flasks (Nunc, Wiesbaden, Germany) were incubated in a humidified atmosphere containing $5 \%$ carbon dioxide at $37^{\circ} \mathrm{C}$. Cells grown for the appropriate time interval were washed with phosphate-buffered saline (PBS, pH 7.4; $140 \mathrm{~mm} \mathrm{NaCl;} 6.5 \mathrm{~mm} \mathrm{Na}$ HPO4; $2.5 \mathrm{~mm} \mathrm{KCl}$; $1.5 \mathrm{mM} \mathrm{KH} 2 \mathrm{PO} 4)$ and harvested by a 3-min treatment with $0.25 \%$ trypsin/0.02\% EDTA (Gibco-BRL/Life Technologies) in PBS. Equal amounts of culture medium were added and cells were centrifuged for $5 \mathrm{~min}$ at $600 \mathrm{~g}$ and resuspended in PBS for further processing.

Cell synchronisation by nocodazole treatment Mitotic arrest was induced by adding $50 \mathrm{ng} \mathrm{ml}^{-1}$ nocodazole (Sigma, Deisen-hofen, Germany) from a $500 \mathrm{mg} \mathrm{ml}^{-1}$ stock solution in dimethyl sulphoxide (DMSO) to the culture medium and incubating the cells for $24 \mathrm{~h}$, as described previously (Endl and Gerdes, 2000). After $24 \mathrm{~h}$ treatment, metaphase cells in $\mathrm{G}_{1}$ were immediately harvested by gentle shaking and washed two times with PBS.

Immunofluorescence and immunohistochemistry As soon as synchronised and unsynchronised cells have been harvested, they were trypsinised, plated (at $1 \times 10^{5} \mathrm{cells} \mathrm{m}^{-1}$ ) on glass slides in six-well cell culture plates and fixed by gently removing the culture medium and adding $2 \%$ formaldehyde in PBS (pH adjusted to 7.4 ) for $10 \mathrm{~min}$ on ice. Cells were permeabilised by incubation in $0.25 \%$ Triton X-100 for $5 \mathrm{~min}$ on ice and washed twice with PBS containing $4 \%$ BSA.

Immediately after this procedure has been completed slides for immunofluorescence were incubated overnight with Ki-67, MCM2, or MCM-5 antibodies at $4{ }^{\circ} \mathrm{C}$, diluted $1: 20$ in a humidified chamber, followed by washing in PBS supplemented with $4 \%$ BSA and incubation with FITC-conjugated anti-mouse secondary antibody diluted 1:200 (Santa Cruz Biotechnology, Santa Cruz, CA, USA) for $1 \mathrm{~h}$ at $4^{\circ} \mathrm{C}$. For immunohistochemistry, the same procedure was followed, substituting FITC-conjugated secondary antibody with DAKO Envision kit, as used for the immunohistochemistry of tissue specimens. Ki-67, MCM-2 and MCM-5 
dilutions in this instance were $1: 300,1: 400$ and $1: 100$, respectively. For both immunohistochemistry and immunofluorescence, each experiment was repeated three times. After washing with PBS, all slides were finally incubated in glycerol and examined under the microscope. Immunofluorescence slides were photographed on fluorescent microscope. At least 300 cells were examined under the microscope at medium and high-power magnification and the percentage of cells displaying nuclear immunoreactivity or immunofluorescence for MCMs and Ki-67 was estimated. Images were stored as TIF files.

\section{Statistical analysis}

The normality of distributions was tested with the KolmogorovSmirnov test. Associations between MCM-2 or MCM-5 LI and histologic type, grade, stage and residual disease were assessed with Mann-Whitney $U$-test and Kruskal-Wallis analysis of variance as appropriate. The correlation between MCM-5 protein and histologic stage when poorly differentiated and unspecified tumours were excluded from analysis was tested using KruskalWallis ANOVA using the Bonferroni correction for multiple comparisons. The interrelations among MCM-2, MCM-5, Ki-67, $\mathrm{p} 53, \mathrm{p} 21^{\mathrm{WAF}}, \mathrm{p} 27^{\mathrm{Kip} 1}$ and Rb, in LMP tumours and adenocarcinomas, were analysed with Spearman's rank correlation coefficient. The Cuzick extension of the Wilcoxon's rank sum test was used to examine the trend of MCM-2 and MCM-5 LI in relation with increasing tumour stage. The difference between MCM-2 or MCM-5 LI and Ki-67 LI in ovarian adenocarcinomas was examined with Wilcoxon's signed rank paired test and in MDAH-2774 with the null hypothesis.

Survival analysis was restricted to adenocarcinomas, given that LMP tumours follow a substantially more favourable clinical course. The prognostic effect of various parameters (i.e. age, histologic type, grade, FIGO stage, volume of residual disease, type of chemotherapy, LI, MCM-2 LI and MCM-5 LI on clinical outcome, i.e. death of disease) was tested by plotting survival curves according to Kaplan-Meier method and comparing groups using the log-rank test, as well as by multivariate analysis. Patients dying of other causes during the follow-up period were treated as censored data. In univariate analysis, the numerical variables age, MCM-2 LI and MCM-5 LI, were categorised on the basis of the median value. In multivariate analysis, we also included Ki-67, $\mathrm{p} 21^{\mathrm{WAF} 1}, \mathrm{p} 27^{\mathrm{Kip} 1}, \mathrm{p} 53$ and $\mathrm{pRb}$ expression to examine whether their presence may influence the prognostic impact of MCM proteins. To avoid any 'data-driven' categorisation, numerical variables were entered in multivariate analysis as continuous variables. Given that MCM-2 and MCM-5 were strongly interrelated, their significance as independent prognosticators was tested in separate models.

Statistical analysis was performed using the SPSS for Windows Software (SPSS Inc., Chicago IL, USA). A P-value of less than or equal to 0.05 was considered indicative of a statistically significant difference.

\section{RESULTS}

\section{MCM-2 and MCM-5 expression in LMP tumours and ovarian adenocarcinomas}

Immunoreactivity for MCM-2 and MCM-5 was seen in all cases ranging from 1 to $82 \%$ (median: $15 \%$ ) and from 1 to $75 \%$ (median: $20 \%$ ), respectively (Figure 1 ). The pattern of staining was mostly nuclear, although a faint cytoplasmic staining was seen in some cases, which was disregarded during evaluation, conforming with previously published data (Meng et al, 2001). Minichromosome maintenance protein-2- and MCM-5-positive cells were randomly distributed throughout the neoplastic population in 110 and 112 cases, respectively. A statistically significant positive correlation was established between MCM-2 and MCM-5 protein levels $(P<0.0001)$.

The median MCM-2 and MCM-5 LIs were significantly higher in adenocarcinomas (20 and 24\%, respectively) compared to LMP tumours (5 and 6\%, respectively) (Mann-Whitney $U$-test, $P<0.0001$ for both associations). When comparisons between LMP cases and carcinomas were made for serous and mucinous types separately, statistically significant differences were recorded for both MCM-2 (Mann-Whitney $U$-test, $P<0.0001$ for serous and $P=0.0070$ for mucinous tumours) and MCM-5 protein expression (Mann-Whitney $U$-test, $P<0.0001$ for serous and $P=0.0020$ for mucinous tumours; Table 2). Within the adenocarcinomas only, MCM-5 (but not MCM-2) protein expression was also related to the histologic type (Kruskal-Wallis ANOVA, $P=0.0349$ ), the highest levels of immunoreactivity being recorded in poorly differentiated and nonspecified categories (Table 3). However, when poorly differentiated and unspecified cases, which are regarded as high-grade disease, were removed from analysis, the relationship failed to reach statistical significance (Kruskal-Wallis ANOVA, Bonferroni correction, $P=0.0856$ ).

\section{Minichromosome maintenance protein-2 and MCM-5 expression in ovarian adenocarcinomas in relation to clinicopathologic parameters}

The rate of MCM-2 or MCM-5 positivity significantly increased with increasing tumour grade ( 1 vs 2 vs 3, Kruskal-Wallis test: $P=0.0002$ and 0.0006 , respectively; Table 4$)$ and the presence of residual disease (Mann-Whitney $U$-test: $P=0.0010$ in both relationships). A statistically significant positive association emerged between MCM-2 and MCM-5 LI and advancing tumour stage (I\&II vs III vs IV, Kruskal-Wallis test: $P=0.0062$ and 0.0018 , respectively; Table 4). The Cuzick extension of the Wilcoxon's rank sum test confirmed the presence of a significant trend of increasing MCM-2 and MCM-5 expression with increasing tumour stage ( $P=0.0100$ and 0.0300 , respectively).

\section{Relationship of MCM-2 LI and MCM-5 LI with proliferation rate}

A strong positive correlation was established between MCM-2 or MCM-5 expression level and Ki-67 LI (Spearman's rho $=0.7214$, $P<0.0001$ and rho $=0.6449, \quad P<0.0001$, respectively), which remained after stratification of our cases into borderline $(P<0.0001$ and 0.0038 , respectively) or carcinoma categories $(P=0.0242$ and $<0.0001$, respectively). Within both the LMP and adenocarcinoma groups MCM-5 (but not MCM-2)-positive cells tended to outnumber Ki-67-positive cells (Wilcoxon's signed rank paired test $P=0.0300$ and 0.0206 , respectively, Figure 2). Within the adenocarcinomas statistically significant differences between MCM-5 and Ki-67 levels were recorded only in grade I tumours $(P=0.0049)$.

\section{Minichromosome maintenance protein-2, MCM-5 and $\mathrm{Ki}-67$ expression in MDAH-2774 cells}

In asynchronous cell culture, a greater number of cells expressed MCM-2 and MCM-5 than Ki-67, the corresponding LIs being 95, 98 and $88 \%$, respectively (MCM-2 vs Ki-67 P=0.0759, MCM-5 vs Ki-67 $P=0.0056)$. This difference remained and even became greater in $G_{1}$ arrested synchronised cells (MCM-2 vs Ki67 $P<0.0001, \mathrm{MCM}-5$ vs Ki-67 $P=0.0039$ ). The LIs in this instance were 79,70 and $50 \%$, respectively, significantly lower than those in asychronous cell culture (MCM-2 $P=0 / 0008$, MCM-5 $P<0.0001$, Ki-67 $P<0.0001$, Figure 3). 

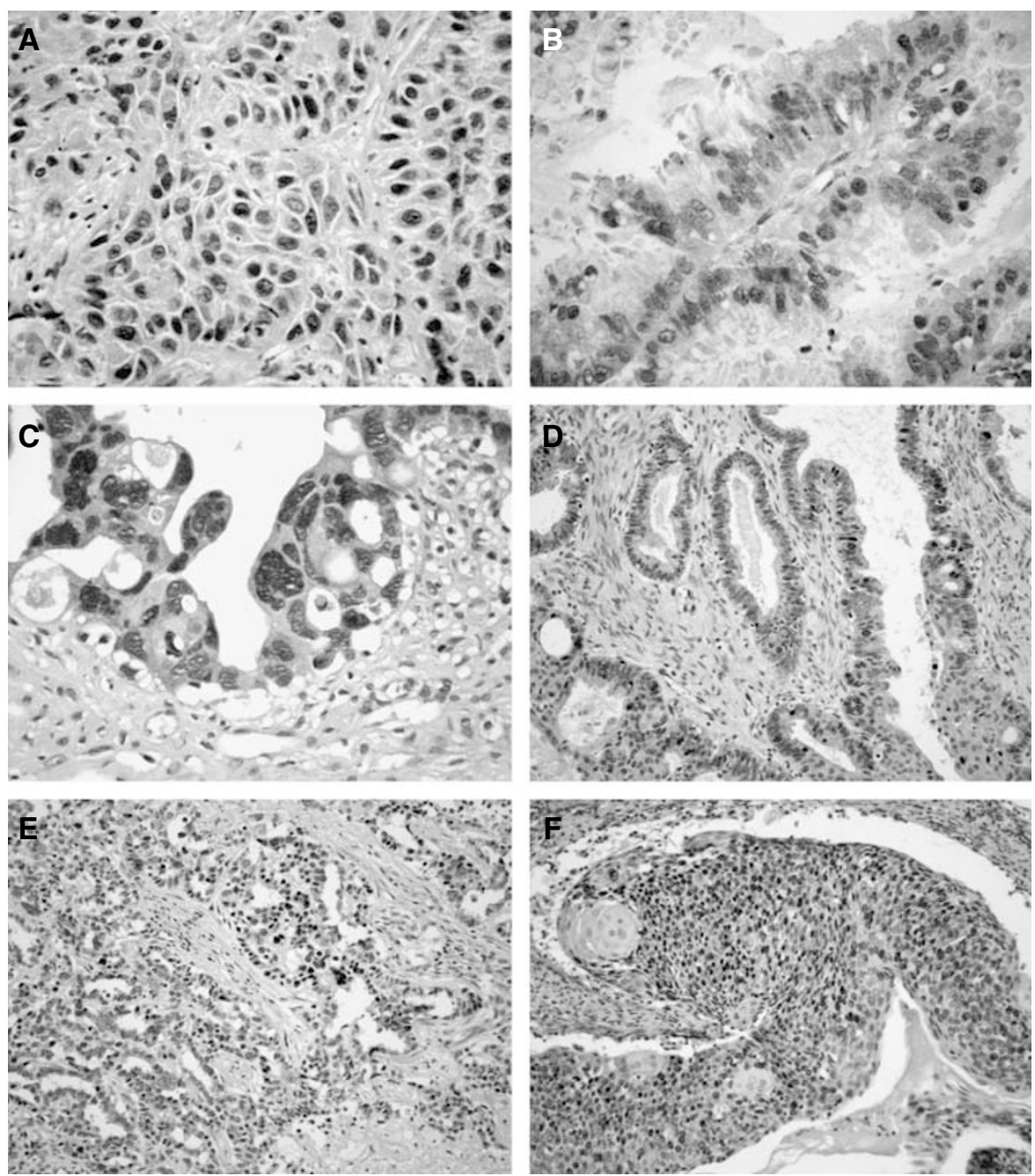

Figure I Immunohistochemical expression of MCM-2 and MCM-5 in ovarian adenocarcinomas. (A) MCM-2 protein expression in many nuclei of a grade 3 endometrioid ovarian adenocarcinoma (original magnification $\times 400$ ). (B) Minichromosome maintenance protein-2 protein expression in a grade I ovarian adenocarcinoma: scattered nuclei stained positive (original magnification $\times 400$ ). (C) Minichromosome maintenance protein-5 protein expression in a grade 3 serous ovarian adenocarcinoma (original magnification $\times 400$ ). (D) Moderate MCM-5 immunopositivity in a grade 2 endometrioid ovarian adenocarcinoma (original magnification $\times 200$ ). (E) Extensive MCM-2 positivity in a grade 2 serous ovarian adenocarcinoma (original magnification $\times 200$ ). (F) Diffuse MCM-5 positivity in a grade 3 endometrioid ovarian adenocarcinoma (original magnification $\times 200$ ).

Table 3 MCM-2 and MCM-5 expression in LMP tumours and ovarian adenocarcinomas

\begin{tabular}{lcc}
\hline Histology & $\begin{array}{c}\text { MCM-2 LI } \\
\text { median (range) }\end{array}$ & $\begin{array}{c}\text { MCM-5 LI } \\
\text { (\%) }\end{array}$ \\
\hline $\begin{array}{l}\text { LMP tumours, } n=42 \\
\text { Serous }\end{array}$ & $5.5(1-25)$ & $10(2-20)$ \\
$\quad$ Mucinous & $5(1-15)$ & $5(1-20)$ \\
Adenocarcinomas, $n=72$ & & \\
$\quad$ Serous & & \\
$\quad$ Mucinous & $20(2-60)$ & $22.5(7-70)$ \\
$\quad$ Endometrioid & $20(8-35)$ & $24(15-70)$ \\
$\quad$ Clear cell & $17.5(8-82)$ & $27.5(8-80)$ \\
Poorly differentiated/ & $15(2-70)$ & $20(5-50)$ \\
Not specified & $35(20-50)$ & $40(10-75)$ \\
\hline
\end{tabular}

\section{Relationship of MCM-2 and MCM-5 expression with p $27^{\mathrm{Kip} 1}, \mathrm{p} 21^{\mathrm{WAF} 1}, \mathrm{p} 53$ and $\mathrm{pRb}$}

In LMP tumours, the levels of MCM proteins did not correlate with either $\mathrm{p} 27^{\mathrm{Kip} 1}, \mathrm{pRb}, \mathrm{p} 21^{\mathrm{WAF} 1}$ or $\mathrm{p} 53$ expression $(P>0.10)$. Also, in ovarian carcinomas, no association was established between p $21^{\mathrm{WAF} 1}$ and MCM-2 or MCM-5 LIs $(P>0.10)$. However, higher MCM-2 or MCM-5 LIs were observed in ovarian adenocarcinomas with p53 Lis $>10 \%$ (Kruskal-Wallis ANOVA $P=0.0022$ and 0.0300 , respectively).

In carcinomas, a statistically significant inverse relation was observed between MCM-2 and p27 ${ }^{\mathrm{Kip} 1}$ levels (Spearman's rho $=-0.3277, P=0.0068$, Figure $4 \mathrm{~A})$. Moreover, statistically significant positive associations emerged between MCM-2 or MCM-5 LI and p53 expression (Spearman's rho $=0.3493$, $P=0.0038$, Figure $4 \mathrm{~B}$ and rho $=0.2348, P=0.0500$, Figure $4 \mathrm{C}$, respectively).

\section{Survival analysis: population group}

In univariate analysis, the parameters adversely affecting survival were high grade $(P=0.0330)$, advanced stage $(P=0.0193)$, the presence of bulk residual disease $(P=0.0001)$, increased $(\geqslant 20 \%)$ MCM-2 expression $(P=0.0004)$ and increased $(\geqslant 25 \%)$ MCM-5 expression $(P=0.0100)$ (Figure 5A and $\mathrm{B})$, whereas histologic type attained a marginal significance in this regard $(P=0.0900)$. 

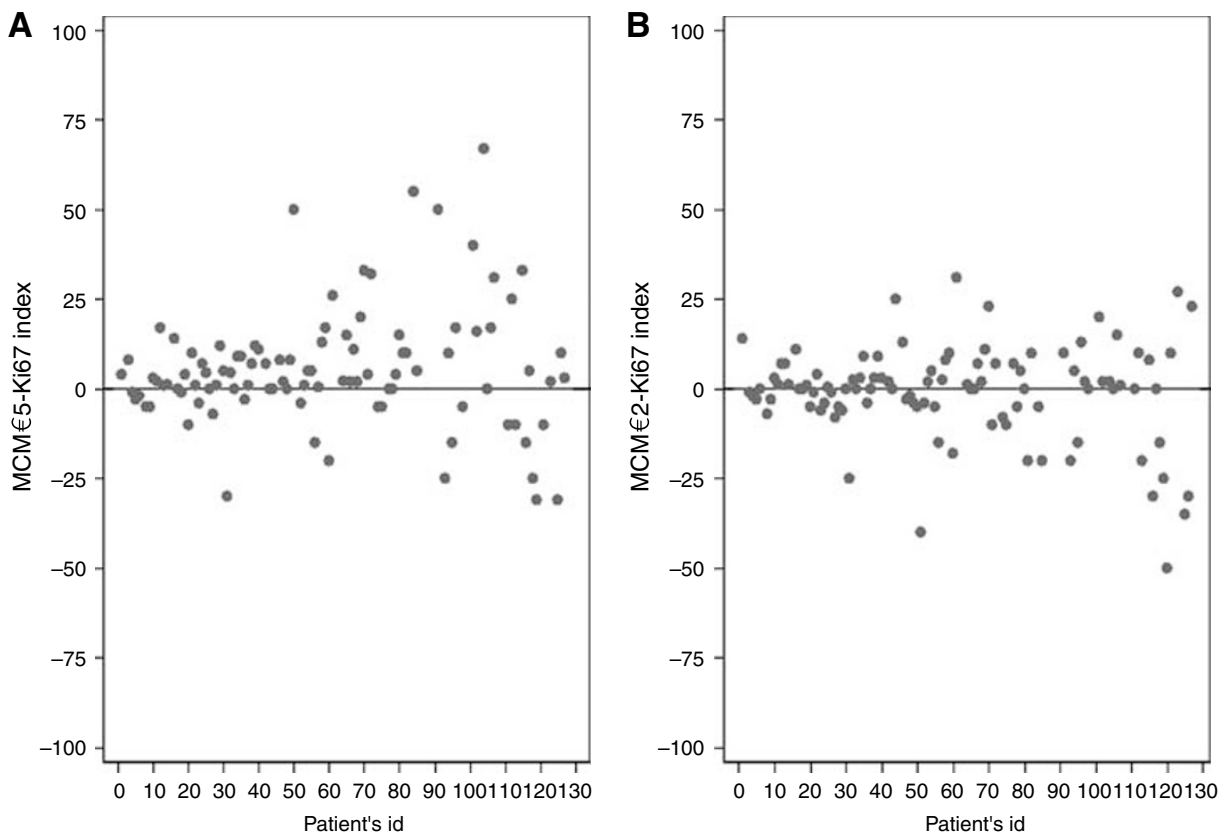

Figure 2 Scatter plot indicating the difference $(\mathbf{A})$ between MCM-5LI and Ki-67LI and (B) between MCM-2LI and Ki-67LI. It is obvious that in the majority of cases the difference between MCM-5 and Ki-67 levels is $>0$.

Table 4 MCM-2 and MCM-5 expression as related to clinicopathologic variables in ovarian carcinomas

\begin{tabular}{lcc}
\hline Variable & $\begin{array}{c}\text { MCM-2 LI } \\
\text { median (range) }\end{array}$ & $\begin{array}{c}\text { MCM-5 LI } \\
\text { (\%) median (range) }\end{array}$ \\
\hline $\begin{array}{l}\text { Histological grade } \\
\text { I }\end{array}$ & $10(2-50)$ & $30(3-70)$ \\
2 & $17.5(5-45)$ & $20(5-60)$ \\
3 & $30(5-82)$ & $42.5(5-80)$ \\
Kruskal-Wallis test & $P=0.0002$ & $P=0.0006$ \\
Stage & & \\
I-II & & $20(3-75)$ \\
III-IV & $15(2-50)$ & $35(5-80)$ \\
Mann-Whitney U test & $20(5-82)$ & $P=0.0018$ \\
Residual tumor & $P=0.0062$ & \\
No & & $20(3-70)$ \\
Yes & $15(2-45)$ & $35(10-80)$ \\
Mann-Whitney U test & $27.5(5-82)$ & $P=0.0010$ \\
\hline
\end{tabular}

In multivariate Cox's proportional hazard analysis of overall survival including MCM-2 LI, stage, grade, histology, chemotherapy and the presence of residual disease, MCM-2 protein expression emerged as an independent predictor of adverse outcome $(P=0.001)$ along with advanced stage of the disease (Table 5, model A1). When multivariate analysis was repeated for MCM-5 and the aforementioned clinicopathological parameters, MCM-5 LI emerged as the only independent predictor of survival $(P=0.0360$; Table 5, model B1) When the other cell cycle regulators were also introduced in the models, MCM-2 remained an independent predictor of survival $(P<0.0001)$ along with the stage of the disease and $\mathrm{p} 21^{\mathrm{WAF} 1}$ expression (Table 5, model A2), whereas MCM-5 remained the only independent predictor of survival against all other parameters examined $(P=0.0220$; Table 5 , model B2).

\section{Univariate survival analysis: validation group}

To detect a difference of 0.5282 between 0.9357 and 0.4093 - the probability of surviving in high MCM-2 $(\geqslant 20 \%)$ and low MCM-2 $(<20 \%)$ expression group after 60.00 months, as calculated in the population group - using a two-sided log-rank test and to achieve $90 \%$ power at a 0.05 significance level, 42 patients would be needed. Accordingly, for the detection of a difference of 0.6745 between 0.9524 and 0.2779 - the probability of surviving in high MCM-5 ( $\geqslant 25 \%)$ and low MCM-5 ( $<25 \%)$ expression group after 60.00 months, as calculated in the population group - using a twosided log-rank test and to achieve $90 \%$ power at a 0.05 significance level 29 patients would be needed. Consequently, we formed a random independent adequately powered validation group of 45 patients with ovarian carcinoma.

Using the optimal cutoff of $20 \%$ for MCM-2 expression and $25 \%$ for MCM-5 expression the 45 patients in the validation group were stratified into low and high expression group. The overall survival was significantly lower in the high MCM-2 expressor group when compared to that in the low MCM-2 expressor group (log-rank test, $P<0.0001)$. The same applied to patients with high MCM-5 expression $((\geqslant 25 \%)$ compared to those with low MCM-5 expression (log-rank test, $P<0.0001)$ ) (Figure 5C and D).

\section{DISCUSSION}

In the present study, we have clearly demonstrated the nuclear localisation of MCM-2 and MCM-5 proteins in ovarian neoplasms. A faint cytoplasmic immunostaining was also seen in some cases, but was not taken into accounting statistical analysis, in keeping with previous observations in urothelial and prostatic carcinomas (Meng et al, 2001; Korkolopoulou et al, 2005). Studies in the budding yeast have documented the distribution of MCM-2 and MCM-3 proteins in both the cytoplasm and nucleus in relatively constant levels throughout the cell cycle (Tye, 1999). However, about $5-10 \%$ of these proteins were tightly associated with chromatin from early $G_{1}$ phase to the beginning of $S$ phase, when replication initiation occurs (Blow and Laskey, 1988), suggesting that active MCM complex is likely to be localised to chromatin. 

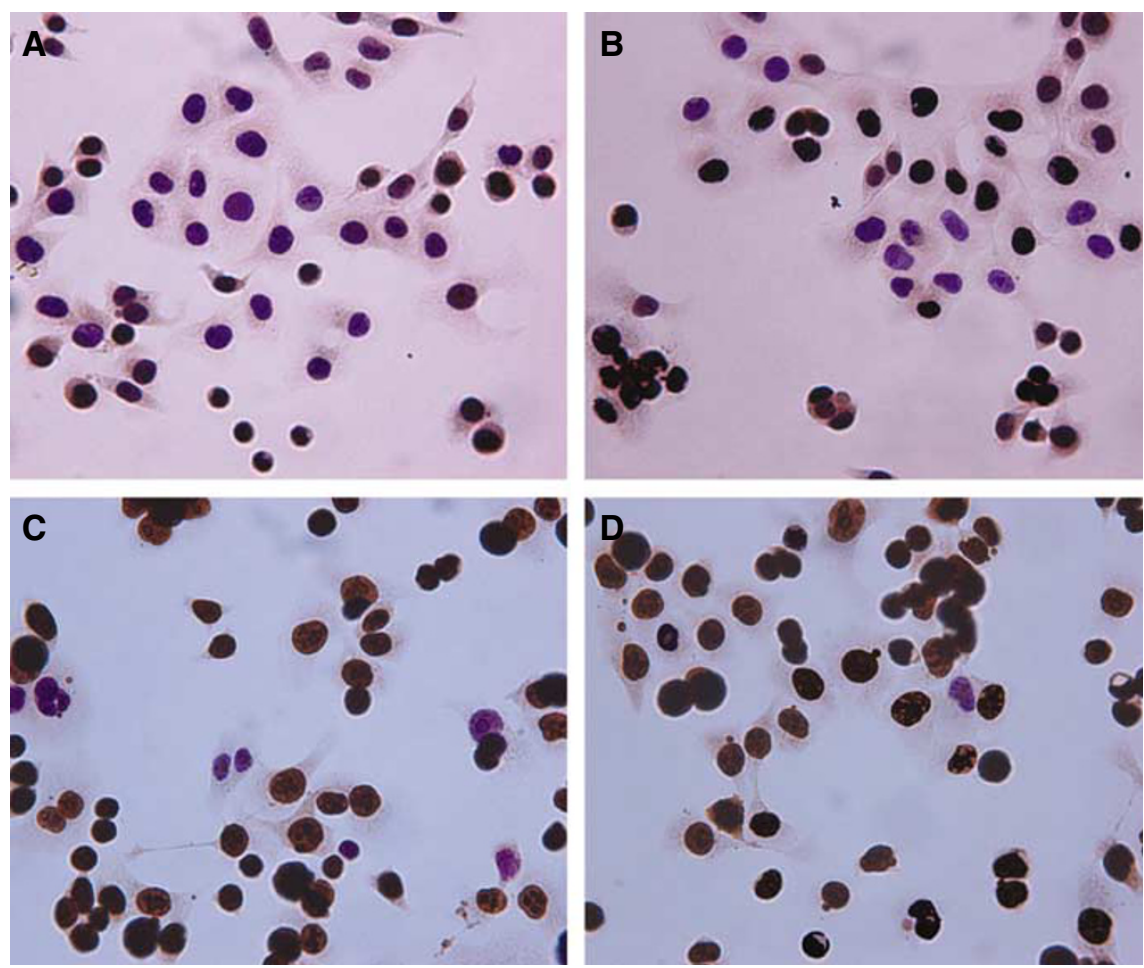

Figure 3 Immunohistochemical expression of MCM-5 and Ki-67 in an ovarian carcinoma cell line: (A) Ki-67 expression in asynchronous cell culture; (B) MCM-5 expression in asynchronous cell culture; (C) Ki-67 expression in $G_{1}$ synchronised cell culture; (D) MCM-5 expression in G, synchronised cell culture $(\times 400)$.
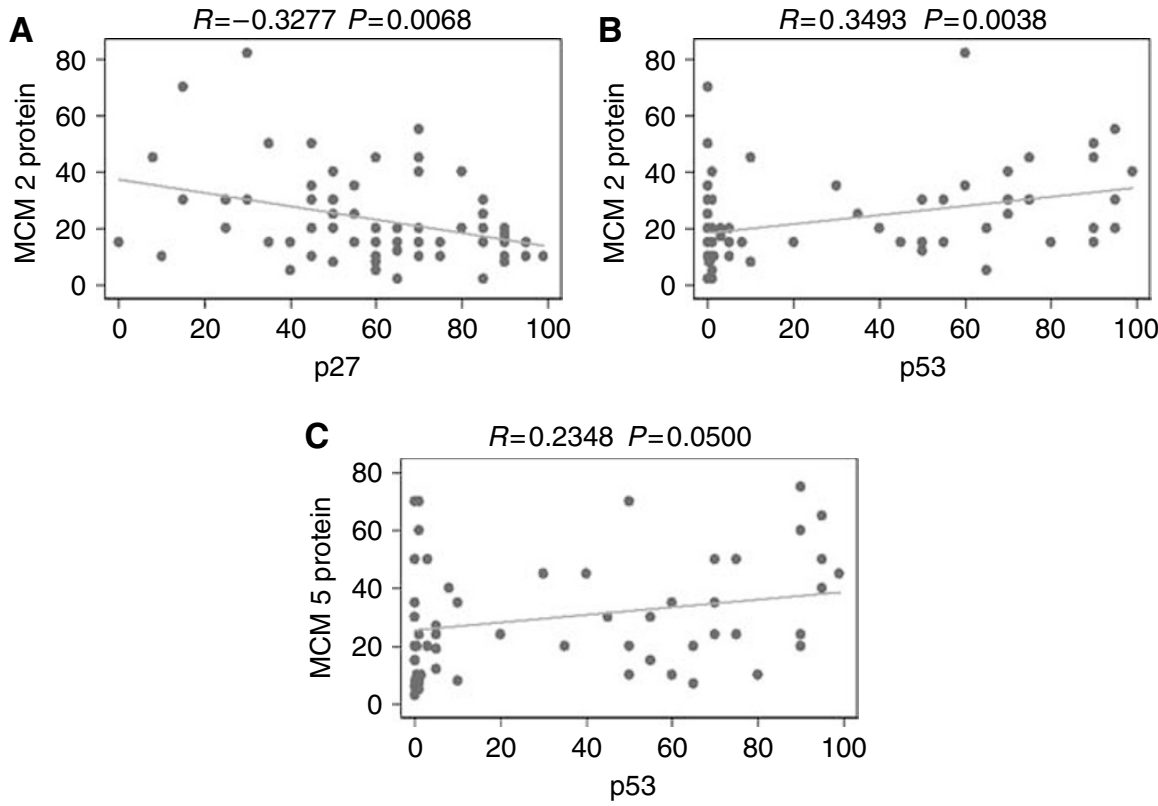

Figure 4 Scatter plot indicating the correlation between MCM-2 LI and p27 LI (A) MCM-2 LI and p53 LI (B) and MCM-5 LI and P53 LI (C).

Yet, nuclear expression and activity are not synonymous terms as nuclear MCM is entirely unbound in $\mathrm{G}_{2}$ (Tye, 1999).

A statistically significant positive correlation was established between MCM-2 and MCM-5 protein levels suggesting the requirement of both proteins to create a functional complex. In this context, various methods have documented the physical interactions among members of the MCM family in man and other organisms (Richter and Knippers, 1997). Thus, immunoprecipitation of one of the MCM proteins often leads to the co-precipitation of all six members of the MCM family (Kubota et al, 1997; Thömmes et al, 1997). Chromatin immunoprecipitation in HeLa cells at the $\mathrm{G}_{1} / \mathrm{S}$-phase transition indicates that all six MCMs colocalise on shared DNA fragments of 500 base pairs, advocating that these proteins are bound to chromatin as a multimeric complex containing all six subunits (Ritzi et al, 1998). 

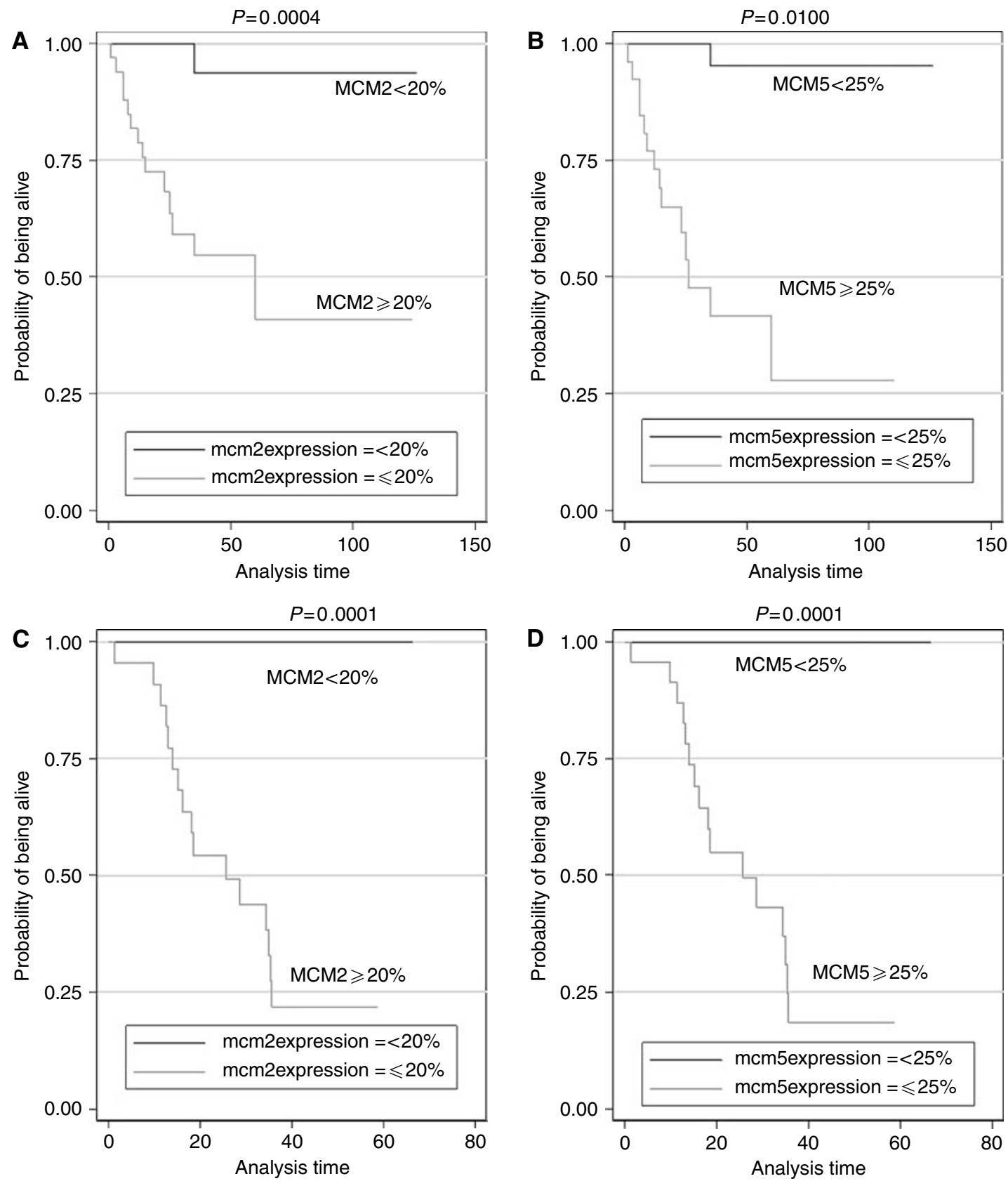

Figure 5 Kaplan-Meier curves of overall survival according to MCM-5 and MCM-2 protein expression in both the population group (A, B) and the validation group $(\mathbf{C}, \mathbf{D})$.

Given that MCMs play a critical role in initiation of DNA synthesis and DNA replication must precede each cell division, their expression is expected to correlate with cell proliferation. Along this line, accumulating evidence highlights the value of MCM protein expression as a novel indicator of cell proliferation (Facoetti et al, 2006). Indeed, in our study, strong correlations emerged between MCM-2 or MCM-5 LIs and the conventional proliferation index Ki-67, which remained even after stratification of our cases into borderline or carcinoma categories. Our work in an ovarian cancer cell line stained immunohistochemically and by immunofluorescence for MCM-2, MCM-5 and Ki-67 verified that MCM-positive cells (especially MCM-5) outnumbered Ki-67positive cells in unsynchronised cells (98vs 88\%) and that this difference became even greater in synchronised cells arrested in $\mathrm{G}_{1}(79$ vs 55\%). However, and in keeping with our previous observations in muscle-invasive urothelial carcinomas (Korkolopoulou et al, 2005), median values of MCM-5 were significantly higher than those of Ki-67 in ovarian carcinomas as well as in LMP tumours. It has been claimed that MCMs represent a potentially more accurate means of determining the proliferative fraction within a tumour than the conventional proliferation indices probably because the latter fail to label cells in early $\mathrm{G}_{1}$ (Osaki et al, 2002; Korkolopoulou et al, 2005; Schrader et al, 2005). However, the discrepancy between MCMLIs and Ki-67 LI might be a reflection of the fact that Ki-67 is downregulated early in the differentiation programme, whereas MCMs are downregulated later, when the cells adopt a terminally differentiated phenotype (Eward et al, 2004; Kingsbury et al, 2005). Thus, the 'improved' sensitivity of MCMs as markers of proliferating cells could reside in the identification of differentiating cells, which is consistent 
Table 5 Cox proportional hazard estimation of overall survival in ovarian adenocarcinomas

$95 \%$ confidence limits for the hazard ratio

\begin{tabular}{|c|c|c|c|c|}
\hline Covariate & $P$ & Hazard ratio & Lower & Upper \\
\hline MCM-2 & 0.001 & 1.058 & 1.023 & 1.093 \\
\hline \multicolumn{5}{|l|}{$\left.B\right|^{b}$} \\
\hline MCM-5 & 0.036 & 1.027 & 1.001 & 1.053 \\
\hline \multicolumn{5}{|l|}{$A 2^{c}$} \\
\hline P2I WAFI & 0.028 & 0.621 & 0.406 & 0.949 \\
\hline \multicolumn{5}{|l|}{$B 2^{d}$} \\
\hline MCM-5 & 0.022 & 1.043 & 1.006 & 1.082 \\
\hline
\end{tabular}

${ }^{\mathrm{a}} \mathrm{A} \mathrm{I}$ model included the conventional clinicopathologic parameters and MCM-2LI. ${ }^{\mathrm{b}} \mathrm{BI}$ model included the conventional clinicopathologic parameters and MCM-5LI. ${ }^{\mathrm{C}} \mathrm{A} 2 \mathrm{model}$ included the conventional clinicopathologic parameters, MCM-2LI, Ki-67LI and the cell cycle regulators. ${ }^{\mathrm{d}} \mathrm{B} 2$ model included the conventional clinicopathologic parameters, MCM$5 \mathrm{LI}, \mathrm{Ki}-67 \mathrm{LI}$ and the cell cycle regulators.

with our finding that the highest difference among MCM-5 and $\mathrm{Ki}-67$ is recorded within the grade I (i.e. the well-differentiated) tumours. Therefore, the higher growth fraction identified by MCMs appears to arise either from the fact that MCMs identify all cell cycle phases, as opposed to the low expression of Ki-67 in early $\mathrm{G}_{1}$ and $\mathrm{M}$ phase, or from the different kinetics of MCMs and Ki-67 downregulation during exit form the mitotic cycle into the differentiated state.

As mentioned above, during early $\mathrm{G}_{1}$, the MCM loading factors Cdc6 and Cdt1 recruit the MCM proteins to chromatin near origins of replication where they remain assembled until late $G_{1}$ phase. $S$ phase is then triggered by high cyclin A/CdK2 and Dbf4/Cdc7 levels that activate the complex of MCM proteins and chromatin (Tachibana et al., 2005). On the other hand, in most normal tissues, $\mathrm{p} 27^{\mathrm{Kip} 1}$ negatively regulates cell proliferation by inhibiting CdKs (Schmider-Ross et al, 2006). Thus, the demonstration in this study of an inverse correlation between $\mathrm{p} 27^{\mathrm{Kip} 1}$ and MCM-2 is in alignment with the underlying mechanism of regulation of cell proliferation.

Although $\mathrm{p} 21^{\mathrm{WAF} 1}$ also constitutes a CdK inhibitor, no association was established between $\mathrm{p} 21^{\mathrm{WAF} 1}$ and MCM-2 or MCM-5 LIs. However, the inhibitory function of $\mathrm{p} 21^{\mathrm{WAF} 1}$ on DNA synthesis requires the formation of quarternary complexes composed of cyclins, CdKs and PCNA and is thought to be stoichiometrically regulated being exerted only when p21 ${ }^{\text {WAF1 }}$ is in molar excess (reviewed by Vassilopoulos et al, 2003). If the ratio of $\mathrm{p} 21^{\mathrm{WAF} 1}$ to CdK is less than one, p21 $1^{\mathrm{WAF1}}$ serves only as an assembling factor for $\mathrm{CdK}$ complex and does not inhibit $\mathrm{CdK}$ activity.

In LMP tumours, the levels of MCM proteins did not correlate with either $\mathrm{p} 27^{\mathrm{Kip} 1}$ or $\mathrm{p} 21^{\mathrm{WAF} 1}$ in keeping with our previous observations concerning Ki-67, p21 $1^{\mathrm{WAF} 1}$ and $\mathrm{p} 27^{\mathrm{Kip} 1}$ expression in LMP ovarian tumours (Korkolopoulou et al, 2002, Vassilopoulos et al, 2003). Palazzo et al (2000) noted a similar lack of correlation between proliferation rate and the levels of p $21^{\mathrm{WAF} 1}$ in LMP tumours. The authors claimed that this finding was to be expected in tumours with a low proliferation index as well as in normal tissues and benign tumours. The low Ki-67 levels in LMP tumours might indicate that most cells are still able to exit from the cell cycle into $\mathrm{G}_{0}$, as opposed to malignant tumours. Following this line of argument, this group of authors (Palazzo et al, 2000) attributed the lack of p21 WAF1 in non-cycling cells to degradation of the protein, once the cell has entered a cell cycle exit state.

Given that p53 immunoreactivity in most carcinomas has been regarded as a surrogate marker for, although not a proof of, gene mutation or inactivation, the observed correlations between
MCM-2 or MCM-5 on one hand and p53 on the other hand might be indicative of the positive effect exerted by mutant-type p53 on cell cycle progression. This concept is reinforced by the fact that higher MCM-2 and MCM-5 LIs were observed in the $32(47.8 \%$ of cases) ovarian adenocarcinomas with p53 LI more than $10 \%$, a cutoff that that has been shown to be efficient for the identification of p53 mutations in paraffin blocks staining (Banks et al, 1986). According to a recent study, p53 mutation prevalence estimates were 45,5 and $1 \%$, respectively, for invasive, LMP and benign ovarian tumours (Reles et al, 2001; Kmet et al, 2003). As opposed to carcinomas, no relation was established between p53 and cell proliferation markers in LMP tumours.

Minichromosome maintenance protein-2 and MCM-5 proteins demonstrated increased expression in ovarian adenocarcinomas as opposed to LMP tumours. These differences remained significant when serous and mucinous neoplasms were investigated separately. Moreover, no difference existed in MCMs expression between serous and mucinous LMP tumours, whereas in adenocarcinomas, a higher level of MCM-5 expression was observed in poorly differentiated category as compared with the remaining histologic types. However, the fact that this correlation did not retain its statistical significance when the poorly differentiated category was removed from analysis could possibly reflect the significant correlation between histologic grade and MCM-5 protein, as poorly differentiated tumours are regarded as high-grade disease. Our findings support and expand the previously reported increase of MCM-2 expression during the progression from normal ovary through serous cystadenoma and serous borderline tumours to serous cystadenocarcinomas (Scott et al, 2004). Consistent with these findings, MCM genes have also been found to be upregulated at the mRNA level in a range of malignancies by expression microarray analysis (Rosenwald et al, 2003; Neben et al, 2004; Yu et al, 2004b). No particular MCM protein appears to be upregulated in isolation, which is consistent with their function as a heterohexameric complex (Tachibana et al, 2005).

In ovarian adenocarcinomas, MCM-2 and MCM-5 expression increased with increasing tumour grade, advancing stage and the presence of bulk residual disease. Significant associations between MCM overexpression and high grade have also been described in prostate (Meng et al, 2001), urothelial (Korkolopoulou et al, 2005) and renal carcinomas (Rodins et al, 2002) as well as in oligodendrogliomas (Wharton et al, 2001). Moreover, in vitro studies have clearly shown a dramatic decrease in the levels of MCM-2 mRNA as well as of MCM-3 protein during the differentiation of human myeloblast HL60 cells (Philipova et al, 
1991; Musahl et al, 1998), respectively, which support our findings. Relevant to this issue is the observation that overexpression of p $21^{\text {WAF1 }}$ or $\mathrm{p} 27^{\mathrm{Kip} 1}$ in the promyelocytic leukemia cell line accelerates its lineage-specific differentiation (Wang et al, 1998; Zhou et al, 1999).

A main scope of our study was to investigate for the first time the prognostic relevance of MCM-2 and MCM-5 expression in ovarian adenocarcinomas. In both univariate and multivariate survival analysis, overexpression of each protein associated significantly with poor overall patients' survival. More importantly, the results of univariate survival analysis were validated in an independent set of patients, using the same cutoff points of MCM expression as in the population study. The confirmation of the adverse prognostic effects of a notorious group of universally established prognostic factors (grade, stage, residual disease) proves that our cohort was quite representative and that survival analysis was valid.

Immunohistochemical studies and expression microarray analyses have independently identified MCM proteins as powerful indicators of worse clinical outcome in various tumour types (Meng et al, 2001; Ramnath et al, 2001; Wharton et al, 2001; Hunt et al, 2002; Rodins et al, 2002; van 't Veer et al, 2002; Gonzalez et al, 2003; Kato et al, 2003; Kodani et al, 2003; Kruger et al, 2003; Rosenwald et al, 2003; Sotiriou et al, 2003; Hashimoto et al, 2004;
Neben et al, 2004; Yu et al, 2004a; Korkolopoulou et al, 2005; Shetty et al, 2005). The MCM genes have also appeared as part of 'poor' prognostic signatures in breast cancer (van 't Veer et al, 2002; Sotiriou et al, 2003; Yu et al, 2004a), mantle cell lymphoma (Rosenwald et al, 2003) and medulloblastoma (Neben et al, 2004), whereas in cervical cancer, MCM protein expression appears promising as a predictor of response to radiation therapy (Mukherjee et al, 2001).

In conclusion, in the present study, we have investigated for the first time MCM-2 and MCM-5 expression in LMP tumours and ovarian adenocarcinomas in relation with clinicopathologic parameters, cell cycle modulators and patients' survival. Both proteins associated significantly with high grade, advanced stage and residual disease as well as with $\mathrm{Ki}-67$ proliferative index. MCM-2 LI was inversely related to CdK inhibitor p $27^{\mathrm{Kip} 1}$, whereas both MCM-proteins correlated positively with p53 expression in carcinomas. MCM-2 and MCM-5, but not Ki-67, emerged as independent predictors of poor overall survival, implying that these molecules may be used to refine the prognostic information conveyed by standard predictors of outcome. On the basis of these findings, the tempting possibility of targeting replication proteins and their regulators as part of antitumour therapies that interfere with cancer cell proliferation certainly merits consideration.

\section{REFERENCES}

Anttila MA, Kosma V-M, Hongxiu J, Puolakka J, Juhola M, Saarikoski S, Syrjänen K (1999) p21/WAF1 expression as related to p53, cell proliferation and prognosis in epithelial ovarian cancer. $\mathrm{Br} J$ Cancer 79: $1870-1888$

Banks L, Matlashewski G, Crawford L (1986) Isolation of human-p53specific monoclonal antibodies and their use in the studies of human p53 expression. Eur J Biochem 159(3): 529-534

Blow JJ, Laskey RA (1988) A role for the nuclear envelope in controlling DNA replication within the cell cycle. Nature 332: 546-548

Cancer Committee of the International Federation of Gynecology and Obstetrics (1986) Staging Announcement. Gynaecol Oncol 25: 383-385

Endl E, Gerdes J (2000) Posttranslational modifications of the KI-67 protein coincide with two major checkpoints during mitosis. J Cell Physiol 182(3): $371-380$

Eward KL, Obermann EC, Shreeram S, Loddo M, Fanshawe T, Williams C, Jung H-II, Prevost AT, Blow JJ, Stoeber K, Williams GH (2004) DNA replication licensing in somatic and germ cells. J Cell Sci 117: 5875-5886

Facoetti A, Ranza E, Benericetti E, Ceroni M, Tedeschi F, Nano R (2006) Minichromosome maintenance protein 7: a reliable tool for glioblastoma proliferation index. Anticancer Res 26: 1071-1075

Freeman A, Morris LS, Mills AD, Stoeber K, Laskey RA, Williams GH, Coleman N (1999) Minichromosome maintenance proteins as biological markers of dysplasia and malignancy. Clin Cancer Res 5: 2121-2132

Gonzalez MA, Pinder SE, Callagy G, Vowler SL, Morris LS, Bird K, Bell JA, Laskey RA, Coleman N (2003) Minichromosome maintenance protein 2 is a strong independent prognostic marker in breast cancer. J Clin Oncol 21: $4306-4313$

Hashimoto K, Araki K, Osaki M, Nakamura H, Tomita K, Shimizu E, Ito H (2004) MCM-2 and Ki-67 expression in human lung adenocarcinoma: prognostic implications. Pathobiology 71: 193-200

Heidebrecht HJ, Buck F, Endl E, Kruse ML, Adam-Klages S, Andersen K, Frahm SO, Schulte C, Wacker HH, Parwaresch R (2001) Ki-Mcm6, a new monoclonal antibody specific to Mcm6: comparison of the distribution profile of Mcm6 and the Ki-67 antigen. Lab Invest 81: 1163-1165

Hunt DPJ, Freeman A, Morris LS, Burnet NG, Bird K, Davies TW, Laskey RA, Coleman N (2002) Early recurrence of benign meningioma correlates with expression of mini-chromosome maintenance-2 protein. $\mathrm{Br} J$ Neurosurg 58: 51-56

Kato H, Miyazaki T, Fukai Y, Nakajima M, Sohda M, Takita J, Masuda N, Fukuchi M, Manda R, Ojima H, Tsukada K, Asao T, Kuwano H (2003) A new proliferation marker, minichromosome maintenance protein 2 , is associated with tumour aggressiveness in esophageal squamous cell carcinoma. J Surg Oncol 84: 24-30

Kingsbury SR, Loddo M, Fanshwave T, Obermann EC, Prevost AT, Stoeber $\mathrm{K}$, Williams GH (2005) Repression of DNA replication licensing in quiescence is independent of geminin and may define the cell cycle state of progenitor cells. Exp Cell Res 309: 56-67

Kmet LM, Cook LS, Magliocco AM (2003) A review of p53 expression and mutation in human benign, low malignant potential, and invasive epithelial ovarian tumors. Cancer 97: 389-404

Kodani I, Osaki M, Shomori K, Araki K, Goto E, Ryoke K, Ito H (2003) Minichromosome maintenance 2 expression is correlated with mode of invasion and prognosis in oral squamous cell carcinomas. J Oral Pathol Med 32: $468-474$

Kodani I, Shomori K, Osaki M, Kuratate I, Ryoke K, Ito H (2001) Expression of minichromosome maintenance 2 (MCM2), Ki-67 and cell cycle-related molecules, and apoptosis in the normal-dysplasia-carcinoma sequence of the oral mucosa. Pathobiology 69: 150-158

Konstantinidou AE, Korkolopoulou P, Vassilopoulos I, Tsenga A, Thymara I, Agapitos E, Patsouris E, Davaris P (2003) Reduced retinoblastoma gene protein to $\mathrm{Ki}-67$ ratio is an adverse prognostic indicator for ovarian adenocarcinoma patients. Gynecol Oncol 88: $369-378$

Korkolopoulou P, Givalos N, Saetta A, Goudopoulou A, Gakiopoulou H, Thymara I, Thomas-Tsagli E, Patsouris E (2005) Minichromosome maintenance proteins 2 and 5 expression in muscle-invasive urothelial cancer: A multivariate survival study including proliferation markers and cell cycle regulators. Hum Pathol 36: 899-907

Korkolopoulou P, Vassilopoulos I, Konstantinidou AE, Zorzos H, Patsouris E, Agapitos E, Davaris P (2002) The combined evaluation of p27 $7^{\mathrm{Kip} 1}$ and Ki-67 expression provides independent information on overall survival of ovarian carcinoma patients. Gynaecol Oncol 85: 404-414

Kruger S, Thorns C, Stocker W, Muller-Kunert E, Bohle A, Feller AC (2003) Prognostic value of MCM2 immunoreactivity in stage T1 transitional cell carcinoma of the bladder. Eur Urol 43: 138-145

Kubota Y, Mimura S, Nishimoto S, Masuda T, Nojima H, Takisawa H (1997) Licensing of DNA replication by a multi-protein complex of MCM/P1 proteins in Xenopus eggs. EMBO J 16: $3320-3331$

Lachin JM (1981) Introduction to sample size determination and power analysis for clinical trials. Control Clin Trials 2: 93-113

Lachin JM, Foulkes MA (1986) Evaluation of sample size and power analysis of survival with allowance for nonuniform patient entry, losses to follow-up noncompliance and stratification. Biometrics 42: 507-519

Labib K, Diffley JF (2001) Is the MCM2-7 complex the eukaryotic DNA replication fork helicase? Curr Opin Genet Dev 11: 64-70

Lei M, Tye BK (2001) Initiating DNA synthesis: from recruiting to activating the MCM complex. J Cell Sci 114: 1447-1454 
Meng MV, Grossfeld GD, Williams GH, Dilworth S, Stoeber K, Mulley TW, Weinberg V, Carroll PR, Tlsty TD (2001) Minichromosome maintenance protein 2 expression in prostate: characterization and association with outcome after therapy for cancer. Clin Cancer Res 7: 2712-2718

Mukherjee G, Freeman A, Moore R, Kumaraswamy P, Devi KU, Morris LS, Coleman N, Dilworth S, Prabhakaran PS, Stanley MA (2001) Biologic factors and response to radiotherapy in carcinoma of the cervix. Int $J$ Gynecol Cancer 11: 187-193

Musahl C, Holthoff HP, Lesch R, Knippers R (1998) Stability of the replicative $\mathrm{Mcm} 3$ protein in proliferating and differentiating human cells. Exp Cell Res 241: $260-264$

Neben K, Korshunov A, Benner A, Wrobel G, Hahn M, Kokocinski F, Golanov A, Joos S, Lichter P (2004) Microarray-based screening for molecular markers in medulloblastoma revealed STK15 as independent predictor for survival. Cancer Res 64: 3103-3111

Osaki M, Osaki M, Yamashita H, Shomori K, Yoshida H, Ito H (2002) Expression of minichromosome maintenance-2 in human malignant fibrous histiocytomas: correlations with Ki-67 and p53 expression, and apoptosis. Int J Mol Med 10: $161-168$

Ozols RF (2002) Update on the management of ovarian cancer. Cancer J 8: $22-30$

Palazzo JP, Monzon F, Burke M, Hyslop T, Dunton C, Barusevicius A, Capuzzi D, Kovatich AJ (2000) Overexpression of $\mathrm{p} 21^{\mathrm{WAF} 1 / \mathrm{C} 1 \mathrm{P} 1}$ and MDM2 characterizes serous borderline ovarian tumors. Hum Pathol 31: $698-704$

Philipova RN, Vassilev AP, Kaneva RP, Andreeva P, Todorov T, Hadjiolov AA (1991) Expression of the nuclear protein mitosin in differentiating in vitro HL60 cells. Biol Cell 72: $47-50$

Ramnath N, Hernandez FJ, Tan DF, Huberman JA, Natarajan N, Beck AF, Hyland A, Todorov IT, Brooks JS, Bepler G (2001) MCM2 is an independent predictor of survival in patients with non-small-cell lung cancer. J Clin Oncol 19: 4259-4266

Reles A, Wen WH, Schmider A, Gee C, Runnebaum IB, Kilian U, Jones LA, El-Naggar A, Minguillon C, Schonborn I, Reich O, Kreienberg R Lichtenegger W, Press MF (2001) Correlation of p53 mutations with resistance to platinum-based chemotherapy and shortened survival in ovarian cancer. Clin Cancer Res 7: 2984-2997

Richter A, Knippers R (1997) High-molecular-mass complexes of human minichromosome-maintenance proteins in mitotic cells. Eur J Biochem 247: $136-141$

Ritzi M, Baack M, Musahl C, Romanowski P, Laskey RA, Knippers R (1998) Human minichromosome maintenance proteins and human origin recognition complex protein on chromatin. J Biol Chem 273: 24543 - 24549

Ritzi M, Knippers R (2000) Initiation of genome replication: assembly and disassembly of replication-competent chromatin. Gene 245: 13-20

Rodins K, Cheale K, Coleman N, Fox SB (2002) Minichromosome maintenance protein 2 expression in normal kidney and renal cell carcinomas: relationship to tumor dormancy and potential clinical utility. Clin Cancer Res 8: 1075-1081

Rosenwald A, Wright G, Wiestner A, Chan WC, Connors JM, Campo E, Gascoyne RD, Grogan TM, Muller-Hermelink HK, Smeland EB, Chiorazzi M, Giltnane JM, Hurt EM, Zhao H, Averett L, Henrickson S Yang L, Powell J, Wilson WH, Jaffe ES, Simon R, Klausner RD, Montserrat E, Bosch F, Greiner TC, Weisenburger DD, Sanger WG, Dave BJ, Lynch JC, Vose J, Armitage JO, Fisher RI, Miller TP, LeBlanc M, Ott G, Kvaloy S, Holte H, Delabie J, Staudt LM (2003) The proliferation gene expression signature is a quantitative integrator of oncogenic events that predicts survival in mantle cell lymphoma. Cancer Cell 3: 185-197

Russel P (1994) Surface epithelial-stromal tumors of the ovary. In: Blaustein's pathology of the female genital tract Kurman RJ (ed), 4th edn, pp 705-782. New York: Springer-Verlag

Schrader C, Janssen D, Klapper W, Siebmann JU, Meusers P, Brittinger G, Kneba M, Tiemann M, Parwaresch R (2005) Minichromosome main tenance protein 6, a proliferation marker superior to Ki-67 and independent predictor of survival in patients with mantle cell lymphoma. Br I Cancer 93: 939-945
Scott IS, Heath TM, Morris LS, Rushbrook SM, Bird K, Vowler SL, Arends MJ, Coleman N (2004) A novel immunohistochemical method for estimating cell cycle phase distribution in ovarian serous neoplasms: implications for the histopathological assessment of paraffin-embedded specimens. Br J Cancer 19(90): $1583-1590$

Scully R, Sobin LH (1987) Histologic typing of ovarian tumours. Arch Pathol Lab Invest 111: $794-795$

Sengupta PS, McGown AT, Bajaj V, Blackhall F, Swindell R, Bromley M (2000) p53 and related proteins in epithelial ovarian cancer. Eur J Cancer 36: $2317-2328$

Shetty A, Loddo M, Fanshawe T, Prevost AT, Sainsbury R, Williams GH, Stoeber K (2005) DNA replication licensing and cell cycle kinetics of normal and neoplastic breast. Br J Cancer 93: 1295-1300

Schmider-Ross A, Pirsig O, Gottschalk E, Denkert C, Lichtenegger W, Reles A (2006) Cyclin-dependant kinase inhibitors CIP1 (p21) and KIP1 (p27) in ovarian cancer. J Cancer Res Clin Oncol 132: $163-170$

Sotiriou C, Neo SY, McShane LM, Korn EL, Long PM, Jazaeri A, Martiat P, Fox SB, Harris AL, Liu ET (2003) Breast cancer classification and prognosis based on gene expression profiles from a population-based study. Proc Natl Acad Sci USA 100: $10393-10398$

Stoeber K, Tlsty TD, Happerfield L, Thomas GA, Romanov S, Bohrow L Williams ED, Williams GH (2001) DNA replication licensing and human cell proliferation. J Cell Sci 114: 2027-2041

Tachibana KK, Gonzalez MA, Coleman N (2005) Cell-cycle-dependent regulation of DNA replication and its relevance to cancer pathology. J Pathol 205: $123-129$

Thömmes P, Kubota Y, Takisawa H, Blow JJ (1997) The RLF-M component of the replication licensing system forms complexes containing all six MCM/P1 polypeptides. EMBO J 16: $3312-3319$

Todorov IT, Pepperkok R, Philipova RN, Kearsey SE, Ansorge W, Werner D (1994) A human nuclear protein with sequence homology to a family of early $S$ phase proteins is required for entry into $S$ phase and for cell division. J Cell Sci 107: 253-265

Todorov IT, Werness BA, Wang HQ, Buddharaju LN, Todorova PD, Slocum HK, Brooks JS, Huberman JA (1998) HsMCM2/BM28: a novel proliferation marker for human tumors and normal tissues. Lab Invest 78: $73-78$

Tye BK (1999) MCM proteins in DNA replication. Annu Rev Biochem 68: $649-686$

van 't Veer LJ, Dai H, van de Vijver MJ, He YD, Hart AA, Mao M, Peterse HL, van der Kooy K, Marton MJ, Witteveen AT, Schreiber GJ, Kerkhoven RM, Roberts C, Linsley PS, Bernards R, Friend SH (2002) Gene expression profiling predicts clinical outcome of breast cancer. Nature 415: $530-536$

Vassilopoulos I, Korkolopoulou P, Konstantinidou AE, Patsouris E, Eftichiadis C, Thymara I, Perdiki M, Pavlakis K, Agapitos E, Davaris PS (2003) Evaluation of the cyclin-dependent kinase inhibitor $\mathrm{p} 21^{\mathrm{Cip}}$ in epithelial ovarian tumors of low malignant potential and adenocarcinomas. Histol Histopathol 18: $761-770$

Wang QM, Shen F, Luo X, Moore DC, Flanagan M, Studzinski GP (1998) Lowering of p27Kip1 levels by its antisense or by development of resistance to 1,25-dihydroxyvitamin D3 reverses the G1 block but not differentiation of HL60 cells. Leukemia 12: 1256-1265

Wharton SB, Chan KK, Anderson JR, Stoeber K, Williams GH (2001) Replicative $\mathrm{Mcm} 2$ protein as a novel proliferation marker in oligodendrogliomas and its relationship to Ki67 labelling index, histological grade and prognosis. Neuropathol Appl Neurobiol 27: 305-313

Yu K, Lee CH, Tan PH, Hong GS, Wee SB, Wong CY, Tan P (2004a) A molecular signature of the Nottingham prognostic index in breast cancer. Cancer Res 64: $2962-2968$

Yu Z, Feng D, Liang C (2004b) Pairwise interactions of the six human MCM protein subunits. J Mol Biol 340: $1197-1206$

Zhou P, Yao Y, Shoh JW, Weistein IB (1999) Overexpression of p21Cip1 or p27Kip1 in the promyelocytic leukemia cell line HL60 accelerates its lineage-specific differentiation. Anticancer Res 19: $4935-4945$ 